\title{
Stimulation of Erythrocyte Death by Phloretin
}

\author{
Rosi Bissinger ${ }^{\mathrm{a}}$ Salome Fischer ${ }^{\mathrm{a}}$ Kashif Jilania ${ }^{\mathrm{a}, \mathrm{b}}$ Florian Lang ${ }^{\mathrm{a}}$ \\ aDepartment of Physiology, University of Tübingen, Germany, bDepartment of Biochemistry, \\ University of Agriculture, Faisalabad, Pakistan
}

\section{Key Words}

Phosphatidylserine $\cdot$ Phloretin $•$ Calcium $•$ Cell volume $・$ Eryptosis

\begin{abstract}
Background: Phloretin, a natural component of apples, pears and strawberries, has previously been shown to stimulate apoptosis of nucleated cells. Erythrocytes may similarly enter suicidal death or eryptosis, which is characterized by cell shrinkage and phospholipid scrambling of the erythrocyte cell membrane with phosphatidylserine translocation to the erythrocyte surface. Stimulators of eryptosis include increase of cytosolic $\mathrm{Ca}^{2+}$-activity $\left(\left[\mathrm{Ca}^{2+}\right]\right)$, ceramide, ATP depletion, and activation of protein kinase $C$ (PKC) as well as p38 mitogen activated protein kinase (p38 kinase). Methods: Phosphatidylserine exposure at the cell surface was estimated from annexin $\mathrm{V}$ binding, cell volume from forward scatter, $\left[\mathrm{Ca}^{2+}\right]_{i}$ from Fluo3-fluorescence, and ceramide abundance from binding of specific antibodies. Results: A $48 \mathrm{~h}$ exposure of human erythrocytes to phloretin significantly increased the percentage of annexin-V-binding cells $(\geq 100 \mu \mathrm{M})$ without significantly influencing forward scatter. Phloretin did not significantly modify $\left[\mathrm{Ca}^{2+}\right]_{i}$ and the stimulation of annexin-V-binding by phloretin $(300 \mu \mathrm{M})$ did not require presence of extracellular $\mathrm{Ca}^{2+}$. Phloretin did not significantly modify erythrocyte ATP levels, and the effect of phloretin on annexin-V-binding was not significantly altered by PKC inhibitor staurosporine $(1 \mu \mathrm{M})$ or p38 kinase inhibitor SB2203580 $(2 \mu \mathrm{M})$. However, phloretin significantly increased the ceramide abundance at the cell surface. Conclusions: Phloretin stimulates phospholipid scrambling of the erythrocyte cell membrane, an effect at least partially due to up-regulation of ceramide abundance.

Copyright $\odot 2014$ S. Karger AG, Basel
\end{abstract}

\section{Introduction}

Phloretin (2',4',6'-trihydroxy-3-(4-hydroxyphenyl)-propiophenone), a component of apples, pears and strawberries [1,2], is a dipolar small molecule interfering with diverse channels and transporters [3-10] including glucose transporters [1, 2]. Effects of Phloretin include decrease of oxidative stress [11], inhibition of inflammation [12], increase 
endothelial nitric oxide production and vasodilation $[13,14]$, downregulation of endothelial adhesion molecules [15], and inhibition of platelet activation [15]. Some of the effects are due to estrogenic activity of the substance $[13,14,16]$. At low concentrations, phloretin has been shown to protect against apoptosis [17]. At high concentrations, phloretin may trigger apoptosis and thus counteract malignancy $[1,2,18-22]$. The stimulation of apoptosis may involve activation of p38 kinase [18].

Similar to apoptosis of nucleated cells, erythrocytes may enter suicidal cell death or eryptosis, which is characterized by cell shrinkage and cell membrane scrambling with translocation of phosphatidylserine from the inner cell membrane leaflet to the cell surface [23]. Eryptosis may be triggered by increase of cytosolic $\mathrm{Ca}^{2+}$ activity $\left(\left[\mathrm{Ca}^{2+}\right]_{\mathrm{i}}\right)$, which leads to cell shrinkage due to activation of $\mathrm{Ca}^{2+}$-sensitive $\mathrm{K}^{+}$channels with subsequent $\mathrm{K}^{+}$exit, hyperpolarization, $\mathrm{Cl}^{-}$exit and thus cellular loss of $\mathrm{KCl}$ and water [24]. Increased $\left[\mathrm{Ca}^{2+}\right]_{\mathrm{i}}$ further triggers cell membrane scrambling with translocation of phosphatidylserine at the erythrocyte surface [23]. Even in the absence of increased $\left[\mathrm{Ca}^{2+}\right]_{i}$, eryptosis may be triggered by ceramide [25]. Eryptosis is further stimulated by energy depletion, activated caspases $[23,26,27]$ and deranged activities of AMP activated kinase AMPK [23], casein kinase $1 \alpha$ [28, 29], cGMP-dependent protein kinase [23], Janus-activated kinase JAK3 [23], protein kinase C [23], p38 kinase [23], PAK2 kinase [23], sorafenib sensitive kinases [30] and sunitinib sensitive kinases [31]. Eryptosis is triggered further by a wide variety of xenobiotics [23, 25, 30-64].

The present study explored, whether phloretin stimulates eryptosis. To this end, human erythrocytes from healthy individuals were treated with phloretin and phosphatidylserine surface abundance, cell volume, $\left[\mathrm{Ca}^{2+}\right]_{i^{\prime}}$, and ceramide abundance at the erythrocyte surface determined by flow cytometry.

\section{Materials and Methods}

Erythrocytes, solutions and chemicals

Fresh Li-Heparin-anticoagulated blood samples were kindly provided by the blood bank of the University of Tübingen. The study is approved by the ethics committee of the University of Tübingen (184/2003 V). The blood was centrifuged at $120 \mathrm{~g}$ for $20 \mathrm{~min}$ at $23^{\circ} \mathrm{C}$ and the platelets and leukocytes-containing supernatant was disposed. Erythrocytes were incubated in vitro at a hematocrit of $0.4 \%$ in Ringer solution containing (in $\mathrm{mM}$ ) $125 \mathrm{NaCl}, 5 \mathrm{KCl}, 1 \mathrm{MgSO}_{4}$, $32 \mathrm{~N}$-2-hydroxyethylpiperazine-N-2-ethanesulfonic acid (HEPES), 5 glucose, $1 \mathrm{CaCl}_{2}$; $\mathrm{pH} 7.4$ at $37^{\circ} \mathrm{C}$ for $48 \mathrm{~h}$. Where indicated, erythrocytes were exposed to phloretin (Sigma Aldrich, Hamburg, Germany) at the indicated concentrations, whereby $25 \mathrm{mg}$ phloretin were solved in 911,51 $\mu$ l DMSO. For comparison, the effect of $3 \mu \mathrm{lDMSO} / \mathrm{ml}$ Ringer was tested.

\section{Analysis of annexin-V-binding and forward scatter}

After incubation under the respective experimental condition, $50 \mu \mathrm{l}$ cell suspension was washed in Ringer solution containing $5 \mathrm{mM} \mathrm{CaCl}_{2}$ and then stained with Annexin-V-FITC (1:200 dilution; ImmunoTools, Friesoythe, Germany) in this solution at $37^{\circ} \mathrm{C}$ for $20 \mathrm{~min}$ under protection from light. In the following, the forward scatter (FSC) of the cells was determined, and annexin-V fluorescence intensity was measured with an excitation wavelength of $488 \mathrm{~nm}$ and an emission wavelength of $530 \mathrm{~nm}$ on a FACS Calibur (BD, Heidelberg, Germany).

\section{Measurement of intracellular $\mathrm{Ca}^{2+}$}

After incubation, erythrocytes were washed in Ringer solution and then loaded with Fluo-3/AM (Biotium, Hayward, USA) in Ringer solution containing $5 \mathrm{mM} \mathrm{CaCl}_{2}$ and $5 \mu \mathrm{M}$ Fluo-3/AM. The cells were incubated at $37^{\circ} \mathrm{C}$ for $30 \mathrm{~min}$ and washed twice in Ringer solution containing $5 \mathrm{mM} \mathrm{CaCl}{ }_{2}$. The Fluo-3/ AM-loaded erythrocytes were resuspended in $200 \mu \mathrm{l}$ Ringer. Then, $\mathrm{Ca}^{2+}$-dependent fluorescence intensity was measured with an excitation wavelength of $488 \mathrm{~nm}$ and an emission wavelength of $530 \mathrm{~nm}$ on a FACS Calibur. 
Determination of ceramide abundance at the erythrocyte surface

To determine ceramide abundance, a monoclonal antibody-based assay was used. After incubation, cells were stained for $1 \mathrm{~h}$ at $37^{\circ} \mathrm{C}$ with $1 \mu \mathrm{g} / \mathrm{ml}$ anti-ceramide antibody (clone MID 15B4; Alexis, Grünberg, Germany) in phosphate-buffered saline (PBS) containing $0.1 \%$ bovine serum albumin (BSA) at a dilution of 1:10. After two washing steps with PBS-BSA, cells were stained for $30 \mathrm{~min}$ with polyclonal fluoresceinisothiocyanate (FITC)-conjugated goat anti-mouse IgG and IgM specific antibody (Pharmingen, Hamburg, Germany) diluted 1:50 in PBS-BSA. Unbound secondary antibody was removed by repeated washing with PBS-BSA. Samples were then analyzed by flow cytometric analysis at an excitation wavelength of $488 \mathrm{~nm}$ and an emission wavelength of $530 \mathrm{~nm}$.

\section{Statistics}

Data are expressed as arithmetic means \pm SEM. As indicated in the figure legends, statistical analysis was made using ANOVA with Tukey's test as post-test and $t$ test as appropriate. $\mathrm{n}$ denotes the number of different erythrocyte specimens studied. Since different erythrocyte specimens used in distinct experiments are differently susceptible to triggers of eryptosis, the same erythrocyte specimens have been used for control and experimental conditions.

\section{Results}

The present study explored whether the antineoplastic alkaloid phloretin modifies eryptosis, the suicidal erythrocyte death, which is characterized by cell membrane scrambling with phosphatidylserine translocation from the cell interior to the cell surface.

Phosphatidylserine exposing erythrocytes were identified utilizing annexin-V-binding in flow cytometry. Annexin-V-binding was estimated by flow cytometry. Prior to measurements the erythrocytes were incubated for 48 hours in Ringer solution without or with phloretin $(100-300 \mu \mathrm{M})$. As shown in Fig. 1, a $48 \mathrm{~h}$ exposure to phloretin increased the percentage of annexin-V-binding erythrocytes, an effect reaching statistical significance at $100 \mu \mathrm{M}$ phloretin concentration. Thus, phloretin treatment leads to erythrocyte cell membrane scrambling with translocation of phosphatidylserine to the cell surface.

In order to test, whether phloretin leads to cell shrinkage, erythrocyte cell volume was estimated from forward scatter in flow cytometry following a 48 hours incubation of human erythrocytes in Ringer solution without or with phloretin $(100-300 \mu \mathrm{M})$. As illustrated in Fig. 2, forward scatter was similar following incubation of human erythrocytes in Ringer solution without and with phloretin $(100-300 \mu \mathrm{M})$.

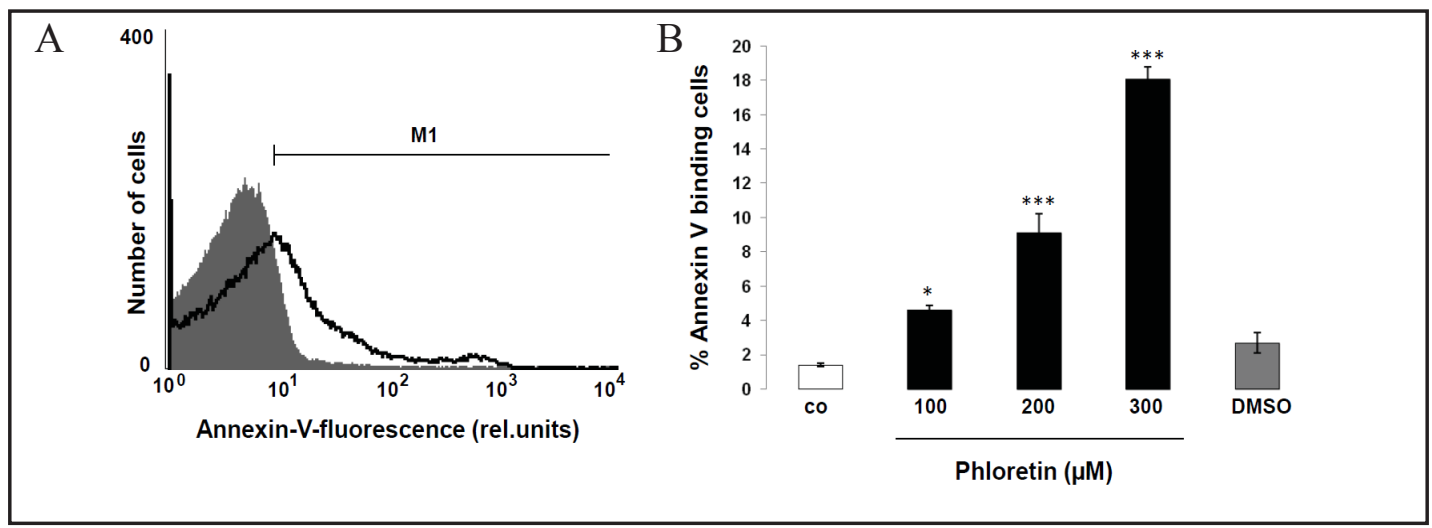

Fig. 1. Effect of phloretin on phosphatidylserine exposure. A. Original histogram of annexin-V-binding of erythrocytes following exposure for $48 \mathrm{~h}$ to Ringer solution without (grey area) and with (black line) presence of $300 \mu \mathrm{M}$ phloretin. B. Arithmetic means \pm SEM of erythrocyte annexin-V-binding $(\mathrm{n}=10)$ following incubation for $48 \mathrm{~h}$ to Ringer solution without (white bar) or with (black bars) presence of phloretin (100-300 $\mu \mathrm{M})$. For comparison, the effect of $3 \mu \mathrm{l}$ DMSO/ml Ringer is shown (grey bar).*(p<0.05), ${ }_{* * *}(\mathrm{p}<0.001)$ indicate significant difference from the absence of phloretin (ANOVA). 


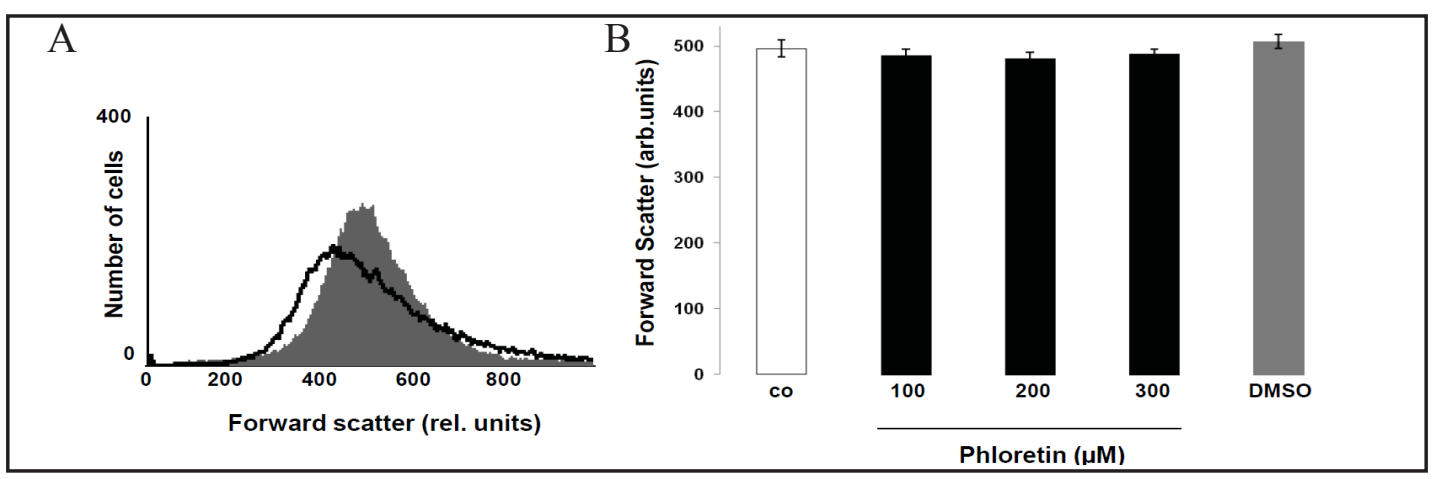

Fig. 2. Effect of phloretin on erythrocyte forward scatter. A. Original histogram of forward scatter of erythrocytes following exposure for $48 \mathrm{~h}$ to Ringer solution without (grey area) and with (black line) presence of $300 \mu \mathrm{M}$ phloretin. B. Arithmetic means \pm SEM $(n=10)$ of the normalized erythrocyte forward scatter (FSC) following incubation for $48 \mathrm{~h}$ to Ringer solution without (white bar) or with (black bars) phloretin $(100-300 \mu \mathrm{M})$. For comparison, the effect of $3 \mu \mathrm{l} \mathrm{DMSO} / \mathrm{ml}$ Ringer is shown (grey bar).

Fig. 3. Effect of phloretin on erythrocyte $\mathrm{Ca}^{2+}$ activity and $\mathrm{Ca}^{2+}$ dependence of phloretin- induced phosphatidylserine exposure. A. Original histogram of Fluo3 fluorescence in erythrocytes following exposure for $48 \mathrm{~h}$ to Ringer solution without (grey area) and with (black line) presence of phloretin $(300 \mu \mathrm{M})$. B. Arithmetic means \pm SEM $(n=10)$ of the Fluo3 fluorescence (arbitrary units) in erythrocytes exposed for $48 \mathrm{~h}$ to Ringer solution without (white bar) or with (black bars) phloretin (100-300 $\mu \mathrm{M})$. For comparison, the effect of $3 \mu \mathrm{l}$ DMSO/ml Ringer (grey bar) and $\mathrm{Ca}^{2+}$ ionophore ionomycin $(1 \mu \mathrm{M}$, $60 \mathrm{~min}$, black bar) is shown. C. Arithmetic means \pm SEM ( $n=4)$ of erythrocyte forward scatter after a $48 \mathrm{~h}$ treatment with Ringer solution without (white bar) or with (black bars) $300 \mu \mathrm{M}$ phloretin in the presence (left bars, + calcium) and absence (right bars, -calcium $)$ of calcium. ${ }^{* * *}(\mathrm{p}<0.001)$ indicates significant difference from the absence of phloretin.

Fluo3 fluorescence was employed to test whether phloretin affected cytosolic $\mathrm{Ca}^{2+}$ activity $\left(\left[\mathrm{Ca}^{2+}\right]_{\mathrm{i}}\right)$. As shown in Fig. 3, a $48 \mathrm{~h}$ exposure to phloretin (100 - 300 $\mu \mathrm{M})$ did not significantly modify Fluo3 fluorescence. Thus, phloretin apparently did not significantly alter cytosolic $\mathrm{Ca}^{2+}$ activity $\left(\left[\mathrm{Ca}^{2+}\right]_{\mathrm{i}}\right)$. As illustrated in Fig. 3, $\left[\mathrm{Ca}^{2+}\right]_{\mathrm{i}}$ was increased by treatment of the erythrocytes with $\mathrm{Ca}^{2+}$ ionophore ionomycin $(1 \mu \mathrm{M}, 1 \mathrm{~h})$. A further series of experiments tested whether the phloretin-induced cell membrane scrambling required entry of extracellular

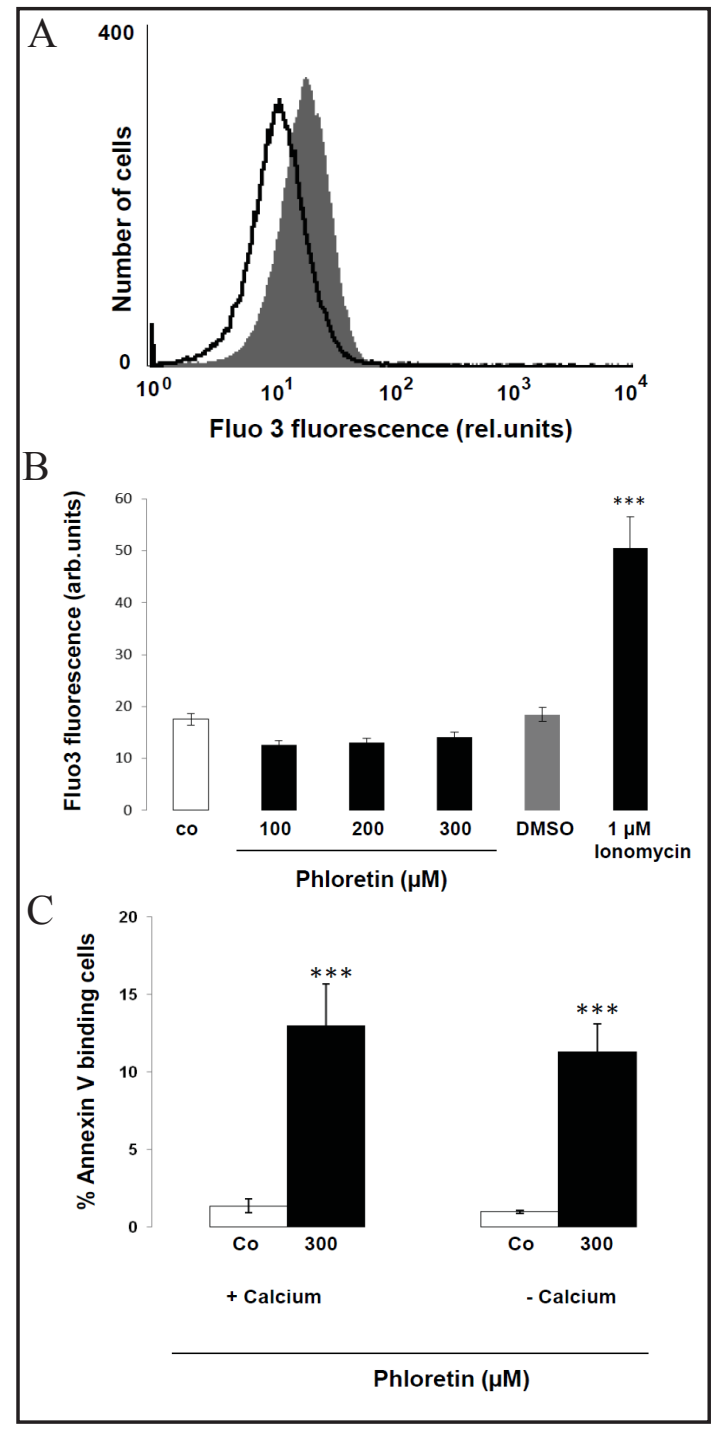
$\mathrm{Ca}^{2+}$. To this end, erythrocytes were exposed for $48 \mathrm{~h}$ to $300 \mu \mathrm{M}$ phloretin in the presence or nominal absence of extracellular $\mathrm{Ca}^{2+}$. As shown in Fig. 3C, phloretin up-regulated annexin-V- 


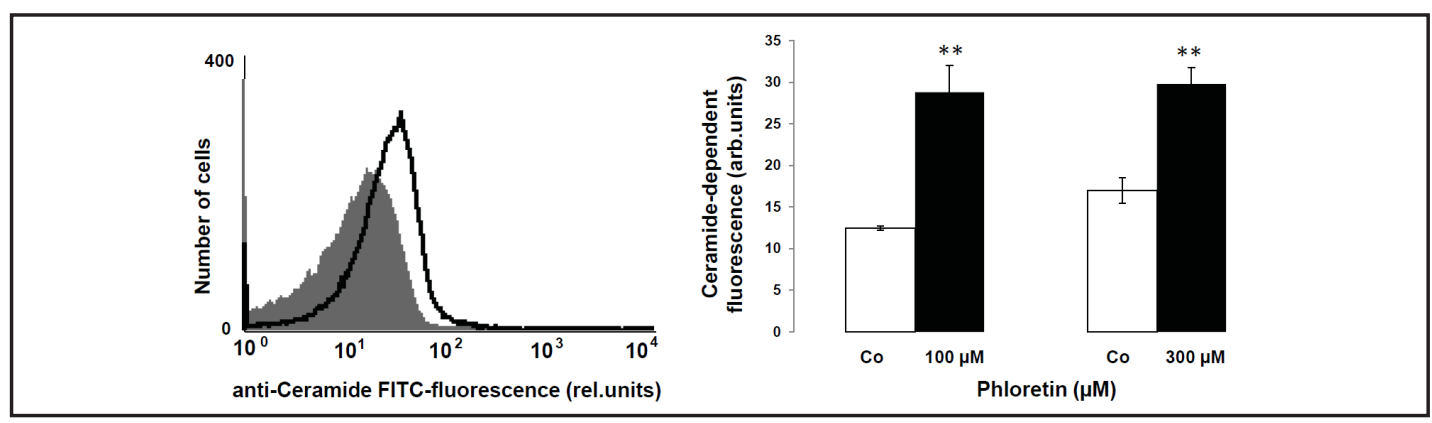

Fig. 4. Effect of phloretin on ceramide formation. A. Original histogram of ceramide surface abundance of erythrocytes following exposure for $48 \mathrm{~h}$ to Ringer solution without (grey shadow) and with (black line) presence of $300 \mu \mathrm{M}$ phloretin. B. Arithmetic means \pm SEM $(n=4)$ of ceramide abundance after a $48 \mathrm{~h}$ incubation in Ringer solution without (white bars) or with $100 \mu \mathrm{M}$ and $300 \mu \mathrm{M}$ phloretin (black bars). ${ }^{* *}(\mathrm{p}<$ 0.01 ) indicates significant difference from the absence of phloretin ( $t$ test).

binding significantly and to a similar extent in the absence and presence of extracellular $\mathrm{Ca}^{2+}$. Thus, the effect of phloretin on phosphatidylserine translocation did not depend on entry of extracellular $\mathrm{Ca}^{2+}$.

In order to test, whether the triggering of cell membrane scrambling was secondary to activation of p38 mitogen activated protein kinase, erythrocytes were exposed for $48 \mathrm{~h}$ to phloretin $(300 \mu \mathrm{M})$ in the absence and presence of the p38 kinase inhibitor SB203580 $(2 \mu \mathrm{M})$. As a result, the phloretin treatment increased the percentage of annexin-V-binding erythrocytes from $1.9 \pm 0.2$ to $19.3 \pm 1.9 \%(n=8)$ in the absence of SB203580, and from 1.7 \pm 0.1 to $18.1 \pm 1.6 \%(n=8)$ in the presence of SB203580. The increase was not significantly different between absence and presence of SB203580. As a positive control, the percentage of phoshatidylserine exposing erythrocytes was, following hyperosmotic shock (addition of $550 \mathrm{mM}$ sucrose, 6 hours), significantly lower in the presence $(11.9 \pm 0.8, \mathrm{n}=8)$ than in the absence $(15.0 \pm 0.6, \mathrm{n}=8)$ of SB203580 $(2 \mu \mathrm{M}, \mathrm{p}<0.001)$.

Further experiments addressed whether the triggering of cell membrane scrambling was secondary to activation of protein kinase C. To this end, erythrocytes were exposed for $48 \mathrm{~h}$ to phloretin $(300 \mu \mathrm{M})$ in the absence and presence of the protein kinase C inhibitor staurosporine $(1 \mu \mathrm{M})$. As a result, the phloretin treatment increased in this series of experiments the percentage of annexin-V-binding erythrocytes from $1.8 \pm 0.3$ to $23.6 \pm 2.1$ $\%(n=8)$ in the absence of staurosporine, and from $2.1 \pm 0.3$ to $23.4 \pm 2.0 \%(n=8)$ in the presence of staurosporine. Again, the increase was not significantly different between absence and presence of staurosporine. As a positive control, the phoshatidylserine exposure following glucose deprivation (48 hours) was significantly lower in the presence (17.2 \pm 0.8 , $\mathrm{n}=8)$ than the absence $(22.7 \pm 1.0, \mathrm{n}=8)$ of staurosporine $(1 \mu \mathrm{M}, \mathrm{p}<0.001)$.

As cell membrane scrambling could result from energy depletion, further experiments tested, whether phloretin decreased the erythrocyte ATP content. As a result, the ATP level approached $0.57 \pm 0.10 \mathrm{mM}(\mathrm{n}=4)$ following a $48 \mathrm{~h}$ incubation in the absence of phloretin and $0.61 \pm 0.11 \mathrm{mM}(\mathrm{n}=4)$ following a $48 \mathrm{~h}$ incubation exposure of erythrocytes in the presence of phloretin $(300 \mu \mathrm{M})$. The respective values were not significantly different. In contrast, a $48 \mathrm{~h}$ incubation of erythrocytes in the absence of glucose was followed by a significant $(p<0.05)$ decrease of the erythrocyte ATP level $(0.18 \pm 0.07 \mathrm{mM}(n=4)$.

As cell membrane scrambling is known to be stimulated by ceramide, which is effective without requirement to increase $\left[\mathrm{Ca}^{2+}\right]_{\mathrm{i}^{\prime}}$, the ceramide abundance at the erythrocyte surface was determined utilizing a specific anti-ceramide antibody. As shown in Figure 4, a $48 \mathrm{~h}$ exposure of erythrocytes to $100 \mu \mathrm{M}$ or $300 \mu \mathrm{M}$ phloretin significantly increased the abundance of ceramide at the erythrocyte surface. The increase of ceramide abundance following treatment of erythrocytes with $300 \mu \mathrm{M}$ phloretin was not significantly modified by acid sphingomyelinase inhibitors, which approached $24.2 \pm 2.1$ u.a. $(n=3)$ in the absence of acid sphingomyelinase inhibitors, $23.7 \pm 1.6$ u.a. $(n=3)$ in the presence of $0.01 \mu \mathrm{M}$ amitriptyline 
and $24.8 \pm 1.8$ u.a. $(\mathrm{n}=3)$ in the presence of $10 \mu \mathrm{M}$ zoledronic acid. The phloretin $(300 \mu \mathrm{M})$ induced increase of phosphatidylserine exposure was similarly not significantly modified by the acid sphingomyelinase inhibitors and approached $14.0 \pm 2.3$ u.a. $(\mathrm{n}=4)$ in the absence of inhibitors, $13.8 \pm 2.3$ u.a. $(\mathrm{n}=4)$ in the presence of $0.01 \mu \mathrm{M}$ amitriptyline and $12.0 \pm 1.5$ u.a. $(\mathrm{n}=4)$ in the presence of $10 \mu \mathrm{M}$ zoledronic acid.

\section{Discussion}

The present study reveals that exposure of erythrocytes to phloretin is followed by cell membrane scrambling with phosphatidylserine translocation to the erythrocyte surface. Cell membrane scrambling is the hallmark of eryptosis, the suicidal death of erythrocytes. The phloretin concentration $(100 \mu \mathrm{M})$ required for stimulation of erythrocyte cell membrane scrambling was similar to that stimulating tumor cell apoptosis [1, 2]. A dosage of $10 \mathrm{mg} /$ $\mathrm{kg}$ was shown to counteract tumor growth in vivo [1]. The in vivo concentrations following application of this dosage have not been reported [1]. Lower concentrations of phloretin are rather protective against apoptosis [17].

Phloretin exposure did not trigger erythrocyte shrinkage, another hallmark of eryptosis. During eryptosis, cell shrinkage is mainly due to increase of cytosolic $\mathrm{Ca}^{2+}$ activity $\left(\left[\mathrm{Ca}^{2+}\right]_{\mathrm{i}}\right)$ with subsequent activation of $\mathrm{Ca}^{2+}$ sensitive $\mathrm{K}^{+}$channels, $\mathrm{K}^{+}$exit, cell membrane hyperpolarization, $\mathrm{Cl}^{-}$exit and thus cellular loss of $\mathrm{KCl}$ with osmotically obliged water [24]. According to Fluo3 fluorescence, phloretin did not increase $\left[\mathrm{Ca}^{2+}\right]_{\mathrm{i}^{*}}$ Moreover, the stimulating effect of phloretin on cell membrane scrambling did not require presence and thus entry of extracellular $\mathrm{Ca}^{2+}$.

The cell membrane scrambling following phloretin exposure was further not secondary to energy depletion, since, other than glucose depletion, phloretin did not decrease the erythrocyte ATP level. Moreover, other than the eryptosis following energy depletion [23], the phloretin-induced cell membrane scrambling was not blunted by the protein kinase $C$ inhibitor staurosporine. Pharmacological inhibition of the p38 kinase, which participates in the triggering of eryptosis following osmotic shock [23], did again not significantly interfere with cell membrane scrambling following phloretin exposure.

According to our observations, the stimulation of cell membrane scrambling is paralleled by an enhancement of ceramide abundance in the erythrocyte cell membrane. The increase could not be inhibited by amitriptyline or zoledronic acid and may thus be due to translocation rather than formation of ceramide. Ceramide is a powerful stimulator of eryptosis [23]. To the best of our knowledge, an increase of ceramide abundance at the cell surface following phloretin exposure has never been shown before.

Phosphatidylserine exposure at the erythrocyte surface serves the function to trigger elimination of defective erythrocytes and thus to protect against hemolysis [23]. Hemolysis of defective erythrocytes inevitably leads to release of hemoglobin, which may be filtered at the renal glomeruli with subsequent precipitation in the acidic lumen of renal tubules and thus occlusion of the affected nephrons [65]. Removal of phosphatidylserine exposing erythrocytes is further of advantage in malaria [66]. The malaria pathogen Plasmodium invades erythrocytes and subsequently induces oxidative stress, which in turn activates several ion channels of the host cell membrane including $\mathrm{Ca}^{2+}$-permeable erythrocyte cation channels $[23,67] . \mathrm{Ca}^{2+}$ entry through those channels triggers eryptosis with rapid clearance of the infected erythrocytes from circulating blood [66]. Accelerated eryptosis counteracts the development of parasitemia and thus favourably influences the clinical course of malaria [66]. Accordingly, several genetic erythrocyte disorders including sickle-cell trait, betathalassemia-trait, homozygous $\mathrm{Hb}-\mathrm{C}$ and homozygous G6PD-deficiency protect against a severe course of malaria at least partially due to accelerated eryptosis [23, 68-70]. The clinical course of malaria is further favourably influenced by clinical conditions with accelerated eryptosis, such as iron deficiency [71], and by xenobiotics triggering eryptosis including lead [72], chlorpromazine [73] or NO synthase inhibitors [74]. In theory, phloretin may similarly influence eryptosis of Plasmodium infected erythrocytes. Beyond that, phloretin is known to interfere with several transport processes in the parasite and/or host erythrocyte [75-81]. 
Accelerated eryptosis may be of pathophysiological significance, as the phagocytosis and subsequent removal of phosphatidylserine exposing erythrocytes may result in anemia as soon as the accelerated clearance of erythrocytes during stimulated eryptosis is not matched by a similarly increased formation of new erythrocytes [23]. Moreover, phosphatidylserine exposing erythrocytes bind to CXCL16/SR-PSO at the apical membrane of endothelial cells in the vascular wall [82]. Phosphatidylserine exposing erythrocytes further stimulate blood clotting and thrombosis [83-85]. Thus, stimulation of phosphatidylserine translocation to the erythrocyte surface may lead to impairment of microcirculation [25, 83, 86-89].

In conclusion, phloretin stimulates erythrocyte cell membrane scrambling, an effect paralleled by and possibly due to increase of ceramide abundance at the ersythrocyte surface.

\section{Acknowledgements}

The authors acknowledge the meticulous preparation of the manuscript by Tanja Loch. The study was supported by the Deutsche Forschungsgemeinschaft and Open Access Publishing Fund of Tuebingen University.

\section{References}

1 Wu CH, Ho YS, Tsai CY, Wang YJ, Tseng H, Wei PL, Lee CH, Liu RS, Lin SY: In vitro and in vivo study of phloretin-induced apoptosis in human liver cancer cells involving inhibition of type II glucose transporter. Int J Cancer 2009;124:2210-2219.

-2 Yang KC, Tsai CY, Wang YJ, Wei PL, Lee CH, Chen JH, Wu CH, Ho YS: Apple polyphenol phloretin potentiates the anticancer actions of paclitaxel through induction of apoptosis in human hep G2 cells. Mol Carcinog 2009;48:420-431.

3 Crespy V, Morand C, Besson C, Manach C, Demigne C, Remesy C: Comparison of the intestinal absorption of quercetin, phloretin and their glucosides in rats. J Nutr 2001;131:2109-2114.

-4 Fan HT, Morishima S, Kida H, Okada Y: Phloretin differentially inhibits volume-sensitive and cyclic AMPactivated, but not Ca-activated, Cl(-) channels. Br J Pharmacol 2001;133:1096-1106.

5 Fenton RA, Chou CL, Stewart GS, Smith CP, Knepper MA: Urinary concentrating defect in mice with selective deletion of phloretin-sensitive urea transporters in the renal collecting duct. Proc Natl Acad Sci U S A 2004;101:7469-7474.

6 Malekova L, Tomaskova J, Novakova M, Stefanik P, Kopacek J, Lakatos B, Pastorekova S, Krizanova O, Breier A, Ondrias K: Inhibitory effect of DIDS, NPPB, and phloretin on intracellular chloride channels. Pflugers Arch 2007;455:349-357.

7 Olson ML, Kargacin ME, Ward CA, Kargacin GJ: Effects of phloretin and phloridzin on Ca2+ handling, the action potential, and ion currents in rat ventricular myocytes. J Pharmacol Exp Ther 2007;321:921-929.

-8 Skriabin G, Orlov S, Masse C, Berthiaume Y: Phloretin inhibits Na+ and K+ uptake in cultured alveolar type II cells by reduction of cellular ATP content. Exp Lung Res 2000;26:319-333.

-9 Sukhorukov VL, Kurschner M, Dilsky S, Lisec T, Wagner B, Schenk WA, Benz R, Zimmermann U: Phloretininduced changes of lipophilic ion transport across the plasma membrane of mammalian cells. Biophys J 2001;81:1006-1013.

10 Zhang S, Morris ME: Effects of the flavonoids biochanin A, morin, phloretin, and silymarin on P-glycoprotein-mediated transport. J Pharmacol Exp Ther 2003;304:1258-1267.

11 Rezk BM, Haenen GR, van der Vijgh WJ, Bast A: The antioxidant activity of phloretin: the disclosure of a new antioxidant pharmacophore in flavonoids. Biochem Biophys Res Commun 2002;295:9-13.

12 Lee JH, Regmi SC, Kim JA, Cho MH, Yun H, Lee CS, Lee J: Apple flavonoid phloretin inhibits Escherichia coli 0157:H7 biofilm formation and ameliorates colon inflammation in rats. Infect Immun 2011;79:4819-4827.

13 Pandey RP, Li TF, Kim EH, Yamaguchi T, Park YI, Kim JS, Sohng JK: Enzymatic synthesis of novel phloretin glucosides. Appl Environ Microbiol 2013;79:3516-3521.

14 Figtree GA, Griffiths H, Lu YQ Webb CM, MacLeod K, Collins P: Plant-derived estrogens relax coronary arteries in vitro by a calcium antagonistic mechanism. J Am Coll Cardiol 2000;35:1977-1985.

15 Stangl V, Lorenz M, Ludwig A, Grimbo N, Guether C, Sanad W, Ziemer S, Martus P, Baumann G, Stangl K: The flavonoid phloretin suppresses stimulated expression of endothelial adhesion molecules and reduces activation of human platelets. J Nutr 2005;135:172-178. 
16 Calliste CA, Le Bail JC, Trouillas P, Pouget C, Habrioux G, Chulia AJ, Duroux JL: Chalcones: structural requirements for antioxidant, estrogenic and antiproliferative activities. Anticancer Res 2001;21:39493956.

17 Choi BM, Chen XY, Gao SS, Zhu R, Kim BR: Anti-apoptotic effect of phloretin on cisplatin-induced apoptosis in HEI-OC1 auditory cells. Pharmacol Rep 2011;63:708-716.

18 Kim MS, Kwon JY, Kang NJ, Lee KW, Lee HJ: Phloretin induces apoptosis in H-Ras MCF10A human breast tumor cells through the activation of p53 via JNK and p38 mitogen-activated protein kinase signaling. Ann N Y Acad Sci 2009;1171:479-483.

19 Kobori M, Iwashita K, Shinmoto H, Tsushida T: Phloretin-induced apoptosis in B16 melanoma 4A5 cells and HL60 human leukemia cells. Biosci Biotechnol Biochem 1999;63:719-725.

-20 Kobori M, Shinmoto H, Tsushida T, Shinohara K: Phloretin-induced apoptosis in B16 melanoma 4A5 cells by inhibition of glucose transmembrane transport. Cancer Lett 1997;119:207-212.

-21 Lee EJ, Kim JL, Kim YH, Kang MK, Gong JH, Kang YH: Phloretin promotes osteoclast apoptosis in murine macrophages and inhibits estrogen deficiency-induced osteoporosis in mice. Phytomedicine 2014;21:1208-1215.

22 Park SY, Kim EJ, Shin HK, Kwon DY, Kim MS, Surh YJ, Park JH: Induction of apoptosis in HT-29 colon cancer cells by phloretin. J Med Food 2007;10:581-586.

-23 Lang E, Qadri SM, Lang F: Killing me softly - suicidal erythrocyte death. Int J Biochem Cell Biol 2012;44:1236-1243.

24 Lang PA, Kaiser S, Myssina S, Wieder T, Lang F, Huber SM: Role of Ca2+-activated K+ channels in human erythrocyte apoptosis. Am J Physiol Cell Physiol 2003;285:C1553-C1560.

25 Abed M, Towhid ST, Mia S, Pakladok T, Alesutan I, Borst O, Gawaz M, Gulbins E, Lang F: Sphingomyelinaseinduced adhesion of eryptotic erythrocytes to endothelial cells. Am J Physiol Cell Physiol 2012;303:C991999.

-26 Lau IP, Chen H, Wang J, Ong HC, Leung KC, Ho HP, Kong SK: In vitro effect of CTAB- and PEG-coated gold nanorods on the induction of eryptosis/erythroptosis in human erythrocytes. Nanotoxicology 2012;6:847856.

27 Maellaro E, Leoncini S, Moretti D, Del Bello B, Tanganelli I, De Felice C, Ciccoli L: Erythrocyte caspase-3 activation and oxidative imbalance in erythrocytes and in plasma of type 2 diabetic patients. Acta Diabetol 2013;50:489-495.

28 Kucherenko Y, Zelenak C, Eberhard M, Qadri SM, Lang F: Effect of casein kinase 1alpha activator pyrvinium pamoate on erythrocyte ion channels. Cell Physiol Biochem 2012;30:407-417.

29 Zelenak C, Eberhard M, Jilani K, Qadri SM, Macek B, Lang F: Protein kinase CK1alpha regulates erythrocyte survival. Cell Physiol Biochem 2012;29:171-180.

30 Lupescu A, Jilani K, Zelenak C, Zbidah M, Qadri SM, Lang F: Hexavalent chromium-induced erythrocyte membrane phospholipid asymmetry. Biometals 2012;25:309-318.

-31 Shaik N, Lupescu A, Lang F: Sunitinib-sensitive suicidal erythrocyte death. Cell Physiol Biochem 2012;30:512-522.

-32 Bottger E, Multhoff G, Kun JF, Esen M: Plasmodium falciparum-infected erythrocytes induce granzyme B by NK cells through expression of host-Hsp70. PLoS One 2012;7:e33774.

-33 Firat U, Kaya S, Cim A, Buyukbayram H, Gokalp 0, Dal MS, Tamer MN: Increased caspase-3 immunoreactivity of erythrocytes in STZ diabetic rats. Exp Diabetes Res 2012;2012:316384.

34 Ganesan S, Chaurasiya ND, Sahu R, Walker LA, Tekwani BL: Understanding the mechanisms for metabolism-linked hemolytic toxicity of primaquine against glucose 6-phosphate dehydrogenase deficient human erythrocytes: evaluation of eryptotic pathway. Toxicology 2012;294:54-60.

35 Gao M, Cheung KL, Lau IP, Yu WS, Fung KP, Yu B, Loo JF, Kong SK: Polyphyllin D induces apoptosis in human erythrocytes through $\mathrm{Ca}(2)(+)$ rise and membrane permeabilization. Arch Toxicol 2012;86:741-752.

-36 Ghashghaeinia M, Cluitmans JC, Akel A, Dreischer P, Toulany M, Koberle M, Skabytska Y, Saki M, Biedermann T, Duszenko M, Lang F, Wieder T, Bosman GJ: The impact of erythrocyte age on eryptosis. Br J Haematol 2012;157:606-614.

-37 Jilani K, Lupescu A, Zbidah M, Abed M, Shaik N, Lang F: Enhanced Apoptotic Death of Erythrocytes Induced by the Mycotoxin Ochratoxin A. Kidney Blood Press Res 2012;36:107-118.

38 Jilani K, Qadri SM, Lang F: Geldanamycin-induced phosphatidylserine translocation in the erythrocyte membrane. Cell Physiol Biochem 2013;32:1600-1609.

-39 Kucherenko YV, Lang F: Inhibitory Effect of Furosemide on Non-Selective Voltage-Independent Cation Channels in Human Erythrocytes. Cell Physiol Biochem 2012;30:863-875. 
40 Lupescu A, Jilani K, Zbidah M, Lang E, Lang F: Enhanced Ca(2+) entry, ceramide formation, and apoptotic death of erythrocytes triggered by plumbagin. J Nat Prod 2012;75:1956-1961.

41 Lupescu A, Jilani K, Zbidah M, Lang F: Induction of apoptotic erythrocyte death by rotenone. Toxicology 2012;300:132-137.

42 Polak-Jonkisz D, Purzyc L: Ca Influx versus Efflux during Eryptosis in Uremic Erythrocytes. Blood Purif 2012;34:209-210.

43 Qian EW, Ge DT, Kong SK: Salidroside protects human erythrocytes against hydrogen peroxide-induced apoptosis. J Nat Prod 2012;75:531-537.

44 Shaik N, Zbidah M, Lang F: Inhibition of $\mathrm{Ca}(2+)$ entry and suicidal erythrocyte death by naringin. Cell Physiol Biochem 2012;30:678-686.

45 Vota DM, Maltaneri RE, Wenker SD, Nesse AB, Vittori DC: Differential erythropoietin action upon cells induced to eryptosis by different agents. Cell Biochem Biophys 2013;65:145-157.

$\checkmark 46$ Weiss E, Cytlak UM, Rees DC, Osei A, Gibson JS: Deoxygenation-induced and $\mathrm{Ca}(2+)$ dependent phosphatidylserine externalisation in red blood cells from normal individuals and sickle cell patients. Cell Calcium 2012;51:51-56.

47 Zappulla D: Environmental stress, erythrocyte dysfunctions, inflammation, and the metabolic syndrome: adaptations to CO2 increases? J Cardiometab Syndr 2008;3:30-34.

48 Zbidah M, Lupescu A, Jilani K, Lang F: Stimulation of suicidal erythrocyte death by fumagillin. Basic Clin Pharmacol Toxicol 2013;112:346-351.

-49 Zbidah M, Lupescu A, Shaik N, Lang F: Gossypol-induced suicidal erythrocyte death. Toxicology 2012;302:101-105.

50 Zelenak C, Pasham V, Jilani K, Tripodi PM, Rosaclerio L, Pathare G, Lupescu A, Faggio C, Qadri SM, Lang F: Tanshinone IIA stimulates erythrocyte phosphatidylserine exposure. Cell Physiol Biochem 2012;30:282294.

51 Abed M, Herrmann T, Alzoubi K, Pakladok T, Lang F: Tannic Acid induced suicidal erythrocyte death. Cell Physiol Biochem 2013;32:1106-1116.

52 Ahmed MS, Langer H, Abed M, Voelkl J, Lang F: The uremic toxin acrolein promotes suicidal erythrocyte death. Kidney Blood Press Res 2013;37:158-167.

53 Ghashghaeinia M, Cluitmans JC, Toulany M, Saki M, Koberle M, Lang E, Dreischer P, Biedermann T, Duszenko M, Lang F, Bosman GJ, Wieder T: Age Sensitivity of NFkappaB Abundance and Programmed Cell Death in Erythrocytes Induced by NFkappaB Inhibitors. Cell Physiol Biochem 2013;32:801-813.

54 Abed M, Feger M, Alzoubi K, Pakladok T, Frauenfeld L, Geiger C, Towhid ST, Lang F: Sensitization of erythrocytes to suicidal erythrocyte death following water deprivation. Kidney Blood Press Res 2013;37:567-578.

55 Alzoubi K, Honisch S, Abed M, Lang F: Triggering of Suicidal Erythrocyte Death by Penta-O-galloyl-beta-dglucose. Toxins (Basel) 2014;6:54-65.

56 Jilani K, Lang F: Carmustine-induced phosphatidylserine translocation in the erythrocyte membrane. Toxins (Basel) 2013;5:703-716.

57 Jilani K, Enkel S, Bissinger R, Almilaji A, Abed M, Lang F: Fluoxetine induced suicidal erythrocyte death. Toxins (Basel) 2013;5:1230-1243.

58 Lupescu A, Bissinger R, Jilani K, Lang F: Triggering of suicidal erythrocyte death by celecoxib. Toxins (Basel) 2013;5:1543-1554.

59 Lupescu A, Jilani K, Zbidah M, Lang F: Patulin-induced suicidal erythrocyte death. Cell Physiol Biochem 2013;32:291-299.

60 Lang E, Qadri SM, Jilani K, Zelenak C, Lupescu A, Schleicher E, Lang F: Carbon monoxide-sensitive apoptotic death of erythrocytes. Basic Clin Pharmacol Toxicol 2012;111:348-355.

61 Abed M, Zoubi KA, Theurer M, Lang F: Effect of dermaseptin on erythrocytes. Basic Clin Pharmacol Toxicol 2013;113:347-352.

62 Arnold M, Lang E, Modicano P, Bissinger R, Faggio C, Abed M, Lang F: Effect of nitazoxanide on erythrocytes. Basic Clin Pharmacol Toxicol 2014;114:421-426.

63 Oswald G, Alzoubi K, Abed M, Lang F: Stimulation of suicidal erythrocyte death by ribavirin. Basic Clin Pharmacol Toxicol 2014;114:311-317.

64 Bissinger R, Malik A, Jilani K, Lang F: Triggering of Erythrocyte Cell Membrane Scrambling by Salinomycin. Basic Clin Pharmacol Toxicol 2014;10.1111/bcpt.12250

65 Harrison HE, Bunting H, Ordway NK, Albrink WS: The Pathogenesis of the Renal Injury Produced in the Dog by Hemoglobin or Methemoglobin. J Exp Med 1947;86:339-356. 
66 Foller M, Bobbala D, Koka S, Huber SM, Gulbins E, Lang F: Suicide for survival--death of infected erythrocytes as a host mechanism to survive malaria. Cell Physiol Biochem 2009;24:133-140.

-68 Ayi K, Giribaldi G, Skorokhod A, Schwarzer E, Prendergast PT, Arese P: 16alpha-bromoepiandrosterone, an antimalarial analogue of the hormone dehydroepiandrosterone, enhances phagocytosis of ring stage parasitized erythrocytes: a novel mechanism for antimalarial activity. Antimicrob Agents Chemother 2002;46:3180-3184.

69 Ayi K, Turrini F, Piga A, Arese P: Enhanced phagocytosis of ring-parasitized mutant erythrocytes: a common mechanism that may explain protection against falciparum malaria in sickle trait and beta-thalassemia trait. Blood 2004;104:3364-3371.

70 Cappadoro M, Giribaldi G, O'Brien E, Turrini F, Mannu F, Ulliers D, Simula G, Luzzatto L, Arese P: Early phagocytosis of glucose-6-phosphate dehydrogenase (G6PD)-deficient erythrocytes parasitized by Plasmodium falciparum may explain malaria protection in G6PD deficiency. Blood 1998;92:2527-2534.

71 Koka S, Foller M, Lamprecht G, Boini KM, Lang C, Huber SM, Lang F: Iron deficiency influences the course of malaria in Plasmodium berghei infected mice. Biochem Biophys Res Commun 2007;357:608-614.

72 Koka S, Huber SM, Boini KM, Lang C, Foller M, Lang F: Lead decreases parasitemia and enhances survival of Plasmodium berghei-infected mice. Biochem Biophys Res Commun 2007;363:484-489.

73 Koka S, Lang C, Boini KM, Bobbala D, Huber SM, Lang F: Influence of chlorpromazine on eryptosis, parasitemia and survival of Plasmodium berghe infected mice. Cell Physiol Biochem 2008;22:261-268.

74 Koka S, Lang C, Niemoeller OM, Boini KM, Nicolay JP, Huber SM, Lang F: Influence of NO synthase inhibitor L-NAME on parasitemia and survival of Plasmodium berghei infected mice. Cell Physiol Biochem 2008;21:481-488.

75 Elliott JL, Saliba KJ, Kirk K: Transport of lactate and pyruvate in the intraerythrocytic malaria parasite, Plasmodium falciparum. Biochem J 2001;355:733-739.

-76 Ginsburg H, Krugliak M: Uptake of L-tryptophan by erythrocytes infected with malaria parasites (Plasmodium falciparum). Biochim Biophys Acta 1983;729:97-103.

77 Ginsburg H, Krugliak M, Eidelman 0, Cabantchik ZI: New permeability pathways induced in membranes of Plasmodium falciparum infected erythrocytes. Mol Biochem Parasitol 1983;8:177-190.

78 Goodyer ID, Hayes DJ, Eisenthal R: Efflux of 6-deoxy-D-glucose from Plasmodium falciparum-infected erythrocytes via two saturable carriers. Mol Biochem Parasitol 1997;84:229-239.

79 Saliba KJ, Kirk K: H+-coupled pantothenate transport in the intracellular malaria parasite. J Biol Chem 2001;276:18115-18121.

-80 Silfen J, Yanai P, Cabantchik ZI: Bioflavonoid effects on in vitro cultures of Plasmodium falciparum. Inhibition of permeation pathways induced in the host cell membrane by the intraerythrocytic parasite. Biochem Pharmacol 1988;37:4269-4276.

81 Tripatara A, Yuthavong Y: Effect of inhibitors on glucose transport in malaria (Plasmodium berghei) infected erythrocytes. Int J Parasitol 1986;16:441-446.

82 Borst O, Abed M, Alesutan I, Towhid ST, Qadri SM, Foller M, Gawaz M, Lang F: Dynamic adhesion of eryptotic erythrocytes to endothelial cells via CXCL16/SR-PSOX. Am J Physiol Cell Physiol 2012;302:C644-C651.

83 Andrews DA, Low PS: Role of red blood cells in thrombosis. Curr Opin Hematol 1999;6:76-82.

84 Chung SM, Bae ON, Lim KM, Noh JY, Lee MY, Jung YS, Chung JH: Lysophosphatidic acid induces thrombogenic activity through phosphatidylserine exposure and procoagulant microvesicle generation in human erythrocytes. Arterioscler Thromb Vasc Biol 2007;27:414-421.

-85 Zwaal RF, Comfurius P, Bevers EM: Surface exposure of phosphatidylserine in pathological cells. Cell Mol Life Sci 2005;62:971-988.

-86 Closse C, Dachary-Prigent J, Boisseau MR: Phosphatidylserine-related adhesion of human erythrocytes to vascular endothelium. Br J Haematol 1999;107:300-302.

87 Gallagher PG, Chang SH, Rettig MP, Neely JE, Hillery CA, Smith BD, Low PS: Altered erythrocyte endothelial adherence and membrane phospholipid asymmetry in hereditary hydrocytosis. Blood 2003;101:46254627.

88 Pandolfi A, Di Pietro N, Sirolli V, Giardinelli A, Di Silvestre S, Amoroso L, Di Tomo P, Capani F, Consoli A, Bonomini M: Mechanisms of uremic erythrocyte-induced adhesion of human monocytes to cultured endothelial cells. J Cell Physiol 2007;213:699-709.

89 Wood BL, Gibson DF, Tait JF: Increased erythrocyte phosphatidylserine exposure in sickle cell disease: flowcytometric measurement and clinical associations. Blood 1996;88:1873-1880. 